\title{
Preparation of monoclonal antibody of anti-feline calicivirus and establishment of double-antibody sandwich enzyme-linked immunosorbent assay detecting method
}

\author{
B. Yuan, C.-X. Ai, L. Yuan, W. Gao, J.-P. Hu, J. Chen and W.-Z. Ren \\ College of Animal Sciences, Jilin University, Changchun, China \\ Corresponding author: W.-Z. Ren \\ E-mail: renwenzhi88@163.com
}

Genet. Mol. Res. 13 (3): 7388-7397 (2014)

Received May 29, 2013

Accepted December 12, 2013

Published September 12, 2014

DOI http://dx.doi.org/10.4238/2014.September.12.4

\begin{abstract}
This study aimed to prepare monoclonal antibody of feline calicivirus (FCV) and identify its basic biological characteristics. Saturated ammonium sulfate precipitation, combined differential centrifugation, and cesium chloride density gradient centrifugation were used for the purification of FCV. The purified FCV was used as antigen to immunize BALB/c mice. The hybridoma lines of anti-FCV monoclonal antibodies were established using cell fusion and hybridoma screening techniques. The subtypes of the monoclonal antibody were identified. The results showed that 3 strains of hybridoma cell lines stably secreted anti-FCV monoclonal antibody; they were named as D8, E5, and H4. The D8 and E5 were IgM subtype antibodies, and $\mathrm{H} 4$ was IgG2b subtype antibody. The monoclonal antibody obtained shared no cross-reactivity with feline parvovirus, canine parvovirus, and canine distemper virus. According to the different recognition sites of 2 monoclonal antibodies E5 and $\mathrm{H} 4$ to the $\mathrm{FCV}$, they were used to coat microtiter plates and prepare 2 enzyme-labeled secondary antibodies to establish double-antibody
\end{abstract}


sandwich enzyme-linked immunosorbent assay detecting method.

Key words: Feline calicivirus; Monoclonal antibodies; Double-antibody sandwich ELISA

\section{INTRODUCTION}

Feline calicivirus (FCV) is also known as feline infectious nose-conjunctivitis virus that can cause upper respiratory tract infection, chronic gastroenteritis, as well as diseases such as oral infections (Hoover and Kahn, 1975; Pedersen et al., 1983; Levy and Marsh, 1992; Waters et al., 1993). It is an important viral disease with a high incidence and worldwide distribution in felines, and it can easily infect one-year-old kittens (Kahn and Gillespie, 1971; Love and Baker, 1972) and result in their death. Since Fastier (1957) first isolated FCV in 1957, FCV could also infect other felines (Levy and Marsh, 1992). Gao et al. (2003) and Kadoi et al. (1997) isolated FCV from the secretions and feces of felines from all over the world. At present, there is no monoclonal antibody technology in China on FCV detection and diagnosis. The common methods to detect the virus were virus isolation, immunofluorescence, and agar immunodiffusion test. These detection methods required long time and had low sensitivity and specificity. The monoclonal antibody had high degree of specificity and homogeneity that showed a wide range of values. In this study, purified FCV was used in immune $\mathrm{BLAB} / \mathrm{c}$ mice, and the cell fusion technology and positive clones screening techniques were used to obtain 2 strains of hybridoma cells with stable secretion of anti-FCV monoclonal antibodies.

\section{MATERIAL AND METHODS}

\section{Materials}

The feline kidney cells (F81) and myeloma cells (SP2/0) were stored in our laboratory. The FCV were provided by Jilin Wu Xing Animal Health Pharmaceutical. The canine parvovirus (CPV), feline parvovirus (FPV), and canine distemper virus (CDV) were stored in our laboratory. SPF female BALB/c mice (aged 6 to 8 weeks and more than 10 weeks used for immunization, cell feeding, and ascite preparation) were purchased from the Experimental Animal Center of Basic Medicine Department, Jilin University. The RPMI 1640, and minimum essential medium (MEM) cell culture mediums were provided by GIBCO, USA. The dimethylsulfoxide (DMSO), Freund's adjuvant, HEPES, $O$-phenylenediamine (OPD), and immunoglobulin standard subclass identification kit were purchased from Sigma, USA. The cell culture plate was provided by Nunc Denmark. The cell cryopreservation pipe and 96-well cell microtiter plates were purchased from Costar, USA. The horseradish peroxidase-conjugated goat anti-mouse IgM antibody was provided by Beijing Zhong Shan Jin Qiao Biotechnology.

\section{Methods}

\section{Antigen preparation}

The FCV was inoculated in feline kidney cells (F81); when the cell lesions reached 70 
to $90 \%$ ( 24 to $48 \mathrm{~h}$ ), the inoculation was stopped. The virus solution obtained was subjected to repeated freezing and thawing 2 to 3 times at $-20^{\circ} \mathrm{C}$. The cells were centrifuged at $8000 \mathrm{rpm}$ for $30 \mathrm{~min}$ to remove cell debris. Equal amount of saturated ammonium sulfate solution was added and mixed using a magnetic stirrer. It was shaken gently for 1 to $4 \mathrm{~h}$ at $4{ }^{\circ} \mathrm{C}$ and kept overnight at $4^{\circ} \mathrm{C}$. The suspension was centrifuged at $8000 \mathrm{rpm}$ for $30 \mathrm{~min}$, and the supernatant was removed. The concentrated FCV was subjected to differential centrifugation at $5000 \mathrm{rpm}$ for 30 $\mathrm{min}$; 10,000 rpm for $30 \mathrm{~min}$; and 38,000 rpm for $60 \mathrm{~min}$. The relatively pure antigen was then obtained. Finally, cesium chloride density gradient centrifugation was performed at 40,000 rpm for $4 \mathrm{~h}$, the virus was purified, and the content of the viral proteins could be detected.

\section{$B A L B / c$ mice immunization}

The 6-8 weeks SPF female BALB/c mice with purified FCV immunization were divided into the experimental and negative control groups. The first immunization was emulsified and intraperitoneally injected with $150 \mu \mathrm{L}$ Freund's complete adjuvant and $150 \mu \mathrm{L}$ purified FCV. The second immunization was emulsified and intraperitoneally injected with $150 \mu \mathrm{L}$ incomplete Freund's adjuvant and $150 \mu \mathrm{L}$ purified FCV. The third immunization was the same as the second immunization, and each immunization interval was 2 weeks. After 3 to 5 days of the third immunization, the tail blood was obtained, and the serum was separated. When the titer reached 1:10,000, the cell fusion was conducted (Love and Baker, 1972; Yin and Liu, 1997). Next, 3 days before the fusion, immunization was strengthened in the mice.

\section{Cell fusion and hybridoma screening}

The well-grown SP2/0 cells in the logarithmic growth phase were selected. The spleen cells were prepared in BALB/c mice with high titer immunization (about $6 \times 10^{7}$ cells). The spleen and myeloma cells were mixed at a $6: 1$ ratio. In a $37^{\circ} \mathrm{C}$ water bath, $1 \mathrm{~mL}$ preheated $50 \%$ PEG 2000 were slowly added for fusion, and the fused cells were added in 96-well cell culture plates that were paved with feeding cells. There was $150 \mu \mathrm{L}$ in each well, and the plates were placed in $5 \% \mathrm{CO}_{2}$ incubator at $37^{\circ} \mathrm{C}$ for culture. On the fifth and tenth day after the fusion, half of the medium was replaced with $20 \%$ HAT medium; on the 12th and 15th day after the fusion, the medium was replaced with $20 \%$ HT medium. When the fusion cells grew to more than $1 / 10$ th of the area of the hole bottoms, the supernatant antibody titer in fused cells hole was detected using ELISA. The positive hybridoma cells were screened, and the limited dilution method was used 3 to 4 times for the subclones until all the clonal cell holes were positive; the hybridoma cell strains secreting anti-FCV were cultured and frozen.

\section{Preparation of ascites}

For this, 8- to 10-week-old female BALB/c mice were selected and intraperitoneally injected with $0.5 \mathrm{~mL}$ sterile liquid paraffin. After 7 to 10 days, the cultured hybridoma cells were blown and centrifuged at $1000 \mathrm{rpm}$ for $4 \mathrm{~min}$. The cell density was adjusted to $10^{5}$ to $10^{6} /$ piece. About 7 days later, the mice abdominal size significantly increased, and the ascites could be collected. The collected ascites were kept at $4^{\circ} \mathrm{C}$ overnight and centrifuged at 5000 $\mathrm{rpm}$ for $5 \mathrm{~min}$. The cellular components and precipitates were removed, and the supernatant was collected for the determination of antibody titer. 


\section{Identification of subclass}

The process was according to instructions of Sigma immunoglobulin standard subclass identification kit.

\section{Purification of ascites}

The acid-ammonium sulfate method (Gondim et al., 2009) was used to purify the monoclonal antibody ascites.

\section{Purity identification of monoclonal antibody}

PAGE.

The purity of the pre-purified and post-purified ascites was identified using SDS-

\section{Hybridoma cell chromosome analysis}

The hybridoma cells entered the logarithmic growth phase 36 to $48 \mathrm{~h}$ after passage. The colchicine at final concentration of $0.4 \mu \mathrm{g} / \mathrm{mL}$ was added at this point. After $4 \mathrm{~h}$ of culture and $3000 \mathrm{rpm}$ centrifugation for $10 \mathrm{~min}, 5 \mathrm{~mL} 0.075 \mathrm{M} \mathrm{KCl}$ preheated at $37^{\circ} \mathrm{C}$ was added, mixed, and placed in a water bath for $20 \mathrm{~min}$ at $37^{\circ} \mathrm{C}$. After 3 times of fixation, glass slides were prepared with Giemsa staining for microscopy observation (Yu and Lu, 1988; Muller et al., 2010).

\section{Peroxidase-marked E5McAb} Galaxybio.

The process was conduced using activated horseradish peroxidase labeling kit from

\section{Establishment of double antibody sandwich ELISA detecting method}

The well-purified E5McAb was appropriately diluted with carbonate buffer (coating buffer). It was packaged on 96 -well polystyrene microtiter plates at $4^{\circ} \mathrm{C}$ overnight. Next, $2 \%$ BSA was used for sealing, and the purified antigens (FCV) were added. The negative control, positive control, and blank control were incubated at $37^{\circ} \mathrm{C}$ for $1 \mathrm{~h}$. The horseradish peroxidase-marked $\mathrm{H} 4 \mathrm{McAb}$ was added and incubated at $37^{\circ} \mathrm{C}$ for $1 \mathrm{~h}$. After chromogenic termination, the $\mathrm{D}_{490}$ values were detected using an enzyme-linked detector. The experimental results were then analyzed.

\section{Double-antibody sandwich ELISA detection optimization}

\section{Determination of the best-applied concentration of FCV and the optimal coating concentration of purified E5McAb (IgG I)}

The well-purified E5McAb (IgG I) was multiple diluted (1:1000, 1:2000, 1:4000, $1: 8000,1: 16000)$. It was packaged in 96 -well polystyrene microtiter plates at $4^{\circ} \mathrm{C}$ overnight. Next, $2 \%$ BSA was used for sealing, and the tested antigens (FCV) were added; the FCV was 
diluted $(1: 20,1: 40,1: 80,1: 160,1: 320)$ and incubated at $37^{\circ} \mathrm{C}$ for $1 \mathrm{~h}$. The horseradish peroxidase $\mathrm{H} 4 \mathrm{McAb}$ was added and the plates were incubated at $37^{\circ} \mathrm{C}$ for $1 \mathrm{~h}$. After chromogenic termination, an enzyme-linked detector was used to detect the $\mathrm{OD}_{490}$ values, and then the experimental results were analyzed.

\section{Best reaction concentration of $\mathrm{HRP}$ enzyme-labeled $\mathrm{H} 4 \mathrm{Mc} A \mathrm{~b}$}

The purified E5McAb was coated in 96-well polystyrene microtiter plates with the best package concentration at $4{ }^{\circ} \mathrm{C}$ overnight. Next, $2 \%$ BSA was used for sealing, and the well-diluted antigen (FCV) was added and incubated at $37^{\circ} \mathrm{C}$ for $1 \mathrm{~h}$. Phosphate buffered saline (PBS) was used to dilute the horseradish peroxidase-labeled H4McAb (1:400, 1:800, $1: 1600,1: 3200,1: 6400)$. There was $100 \mu \mathrm{L}$ solution per well, and the plates were incubated at $37^{\circ} \mathrm{C}$ for $1 \mathrm{~h}$. After chromogenic termination, an enzyme-linked detector was used to detect the $\mathrm{OD}_{490}$ values, and then the experimental results were analyzed.

\section{Determination of substrate acting time}

The purified E5McAb was coated in 96-well polystyrene microtiter plates with the best package concentration at $4{ }^{\circ} \mathrm{C}$ overnight. Next, $2 \%$ BSA was used for sealing, and the well-diluted antigen (FCV) was added and incubated at $37^{\circ} \mathrm{C}$ for $1 \mathrm{~h}$. The horseradish peroxidase-labeled $\mathrm{H} 4 \mathrm{McAb}$ was added and incubated at $37^{\circ} \mathrm{C}$ for $1 \mathrm{~h}$. The staining solution was added, and the staining times were used to divide the plates into 4 groups. Group 1: dark staining for $10 \mathrm{~min}$; Group 2: dark staining for $15 \mathrm{~min}$; Group 3: dark staining for $20 \mathrm{~min}$; and Group 4: dark staining for $25 \mathrm{~min}$. After chromogenic termination, the enzyme-linked detector was used to detect the $\mathrm{OD}_{490}$ values, and then the experimental results were analyzed.

\section{Specific test}

The FCV, CDV, CPV, FPV, and CAV-1 were used as the tested antigens. The established double antibody sandwich ELISA method was used for the detection, and the SP2/0 cell supernatant was used as the negative control.

\section{RESULTS}

\section{TEM observations of the virus form}

Negative-staining electron microscopy observation revealed that the FCV showed icosahedral symmetry with the diameter of 35 to $39 \mathrm{~nm}$; it had no capsular membrane. After purification, the FCV showed many virus particles but few contaminating proteins. This ensured the immunogenicity of the antigen and the immune effects of the fused mouse (Figure 1).

\section{Specific detection of the monoclonal antibody}

\section{Detection of the hybridoma cultured supernatant and mouse ascites titers}

In all, 3 strains of the hybridoma cell lines and ascites were indirectly detected using ELISA; the results are shown in Table 1. 


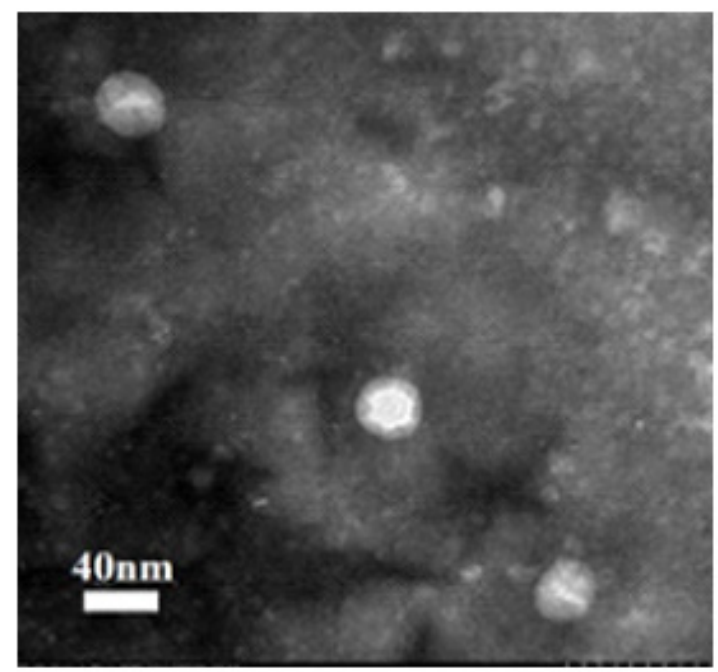

Figure 1. Electron microscopy negative staining results of the purified FCV.

Table 1. Titer determination of the supernatant and ascites.

\begin{tabular}{lcc}
\hline Cell strains & Supernatant titer & Ascites titer \\
\hline $\mathrm{G}_{3}$ & $2^{7}$ & $1000 \times 2^{7}$ \\
$\mathrm{C}_{2}$ & $2^{7}$ & $1000 \times 2^{7}$ \\
$\mathrm{H}_{2}$ & $2^{7}$ & $1000 \times 2^{7}$ \\
\hline
\end{tabular}

\section{Monoclonal antibody subclass identification}

The monoclonal antibody subclass identification kit (Sigma) was used for the subclass identification of the 3 strains of cell lines, namely, D8, E5, and H4; the subclass identification results are shown in Table 2.

Table 2. Monoclonal antibody subclass identification.

\begin{tabular}{lcccccc}
\hline Cell strains & IgM & IgG1 & IgG2a & IgG2b & IgG3 & IgA \\
\hline D8 & 1.437 & 0.079 & 0.085 & 0.062 & 0.114 & 0.107 \\
E5 & 1.539 & 0.073 & 0.057 & 0.058 & 0.097 & 0.084 \\
H4 & 0.113 & 0.084 & 0.071 & 1.796 & 0.088 & 0.087 \\
\hline
\end{tabular}

\section{Monoclonal antibody purity identification}

The caprylic acid-saturated ammonium sulfate method was used for the purification of the mouse ascites, and the obtained monoclonal antibodies were identified using SDS-PAGE. The results are shown in Figure 2. After the SDS-PAGE identification of the purified ascites, 2 clear bands of 55 and $25 \mathrm{kDa}$ were noted, and the contaminating proteins were few. 


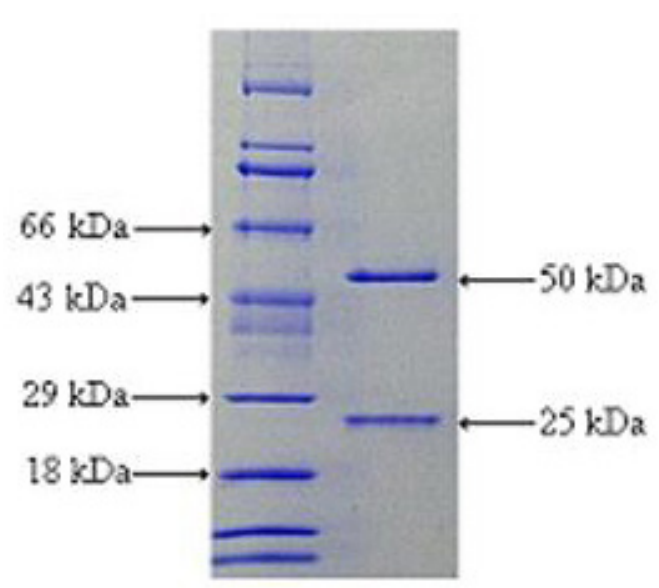

Figure 2. SDS-PAGE detection of purified of monoclonal antibody.

\section{Chromosome analysis results of hybridoma cells}

The chromosome number of the spleen cells in the normal BALB/c mouse was 40, and that of the myeloma cells was 60 to 70; the fusion chromosome number was between 100 and 110. The results are shown in Figure 3.

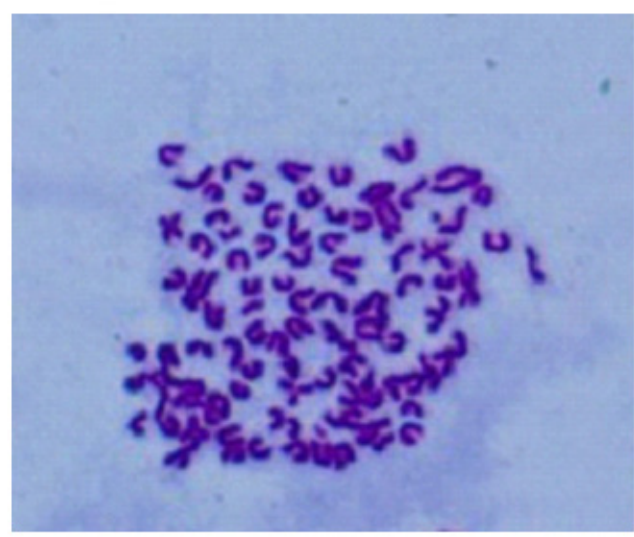

Figure 3. Chromosome number of the hybridoma cells.

\section{Optimization of double-antibody sandwich ELISA method}

According to the double-antibody sandwich ELISA test results, the optimum packet concentration of E5McAb (IgG I) was 1:4000. The best-used concentration of FCV was 1:40. The data are shown in Table 3. 
Table 3. Determination of the IgG I package concentration and the best used concentration of feline calicivirus (FCV).

\begin{tabular}{lccccc}
\hline IgG I dilution times & \multicolumn{4}{c}{ FCV antigen dilution times } \\
\cline { 2 - 6 } & $1: 20$ & $1: 40$ & $1: 80$ & $1: 160$ & $1: 320$ \\
\hline $1: 1000$ & 2.112 & 1.907 & 1.692 & 1.535 & 1.003 \\
$1: 2000$ & 1.912 & 1.879 & 1.225 & 0.908 & 0.831 \\
$1: 4000$ & 1.396 & 1.032 & 1.004 & 0.606 & 0.713 \\
$1: 8000$ & 1.197 & 0.932 & 0.847 & 0.441 & 0.496 \\
$1: 16000$ & 0.896 & 0.756 & 0.637 & \\
\hline
\end{tabular}

According to the double-antibody sandwich ELISA test results, the optimal dilution of HRP enzyme-labeled H4 McAb (IgG II) was 1:1000. The data are shown in Table 4.

Table 4. Determination of the best reaction concentration of IgG II.

\begin{tabular}{lllllr}
\hline & \multicolumn{5}{c}{ IgG II dilution times } \\
\cline { 2 - 6 } & $1: 400$ & $1: 800$ & $1: 1600$ & $1: 3200$ & $1: 6400$ \\
\hline OD value & 1.471 & 1.147 & 0.878 & 0.592 & 0.369 \\
\hline
\end{tabular}

According to the double-antibody sandwich ELISA test results, the best substrate chromogenic time was 10 to $15 \mathrm{~min}$. The data are shown in Table 5.

Table 5. Substrate reaction time.

\begin{tabular}{lcccc}
\hline & \multicolumn{4}{c}{ Different substrate reaction time } \\
\cline { 2 - 5 } & $10 \mathrm{~min}$ & $15 \mathrm{~min}$ & $20 \mathrm{~min}$ & $25 \mathrm{~min}$ \\
\hline OD value & 1.032 & 1.057 & 1.339 & 1.458 \\
\hline
\end{tabular}

\section{Specific test}

The established double-antibody sandwich ELISA test results are shown in Table 6.

Table 6. Specific test results.

\begin{tabular}{lcccccr}
\hline & \multicolumn{5}{c}{ Different coating antigens } \\
\cline { 2 - 7 } & FCV & CDV & CPV & FPV & CAV-1 & SP2/0 supernatant \\
\hline OD value & $1.876 /+$ & $0.183 /-$ & $0.179 /-$ & $0.191 /-$ & $0.176 /-$ & $0.183 /-$ \\
\hline
\end{tabular}

$\mathrm{FCV}=$ feline calicivirus; $\mathrm{CDV}=$ canine distemper virus; $\mathrm{CPV}=$ canine parvovirus; $\mathrm{FPV}=$ feline parvovirus.

\section{DISCUSSION}

The purification of FCV was the foundation and key for producing monoclonal antibodies. The high-purified antigens could directly affect the positive rate screening of the fused cells to facilitate screening (SiTu et al., 2004; Wang et al., 2008). During purification, to ensure that the natural structure of the FCV was retained, the virus was obtained in the pure form as 
far as possible to maintain its immunogenicity. Our study used saturated ammonium sulfate precipitation, combined differential centrifugation, and cesium chloride density gradient centrifugation to purify the virus and remove cell debris and contaminating proteins. This process might activate B lymphocytes to secrete antibodies against virus surface antigen epitopes. The cell fusion was the most critical aspect in the monoclonal antibody preparation process. A high level of cell fusion rate was important to ensure that positive hybridoma cells could be screened out. Many factors can affect cell fusion, particularly the status of myeloma cells; hence, selecting myeloma cells with a smooth surface and in the logarithmic growth phase was essential. The proportion of cells can also affect the growth and screening of hybridoma cell lines. In the present study, PEG1000, and not the high-molecular-weight PEG, was used for cell fusion; this caused less damage to the cells and provided a higher fusion rate.

After cell fusion, hybridoma cell screening was conducted to avoid the loss of positive hybridoma cells secreting specific antibodies due to competitive inhibition. After 3 consecutive cloning, the positive rate reached $100 \%$. This experiment successfully screened out 3 strains of anti-FCV monoclonal antibody hybridoma cell lines; the monoclonal antibodies had high specificity and sensitivity.

When establishing double-antibody sandwich ELISA detecting method, long reaction time and high concentration of the 2 enzyme-labeled antibodies would increase the nonspecific adsorption to yield higher positive values. Short reaction times and low concentrations would cause insufficient binding of antigenic epitopes and yield lower positive values. We determined that the optimal reaction conditions for the double-antibody sandwich ELISA detecting method were $1 \mathrm{~h}$ at $37^{\circ} \mathrm{C}$ and the optimal dilution time was $1: 1000$.

\section{ACKNOWLEDGMENTS}

(\#20071138, \#201101015).

\section{REFERENCES}

Gao YW, Xia XZ, Hu RL and et al. (2003). Cheetah and tiger feline calicivirus isolation and hypervariable region gene. Zhong Guo Yu Fang Shou Yi Xue Bao 5: 179-182.

Gondim LF, Lindsay DS and McAllister MM (2009). Canine and bovine Neospora caninum control sera examined for cross-reactivity using Neospora caninum and Neospora hughesi indirect fluorescent antibody tests. J. Parasitol. 95: 86-88.

Hoover EA and Kahn DE (1975). Experimentally induced feline calicivirus infection: clinical signs and lesions. J. Am. Vet. Med. Assoc. 166: 463-468.

Kadoi K, Kiryu M, Iwabuchi M, Kamata H, et al. (1997). A strain of calicivirus isolated from lions with vesicular lesions on tongue and snout. New Microbiol. 20: 141-148.

Kahn DE and Gillespie JH (1971). Feline viruses: pathogenesis of picornavirus infection in the cat. Am. J. Vet. Res. 32: 521-531.

Levy JK and Marsh A (1992). Isolation of calicivirus from the joint of a kitten with arthritis. J. Am. Vet. Med. Assoc. 201: 753-755.

Love DN and Baker KD (1972). Sudden death in kittens associated with a feline picornavirus. Aust. Vet. J. 48: 643.

Muller C, Sieber-Ruckstuhl N, Decaro N, Keller S, et al. (2010). Infectious canine hepatitis in 4 dogs in Switzerland. Schweiz. Arch. Tierheilkd. 152: 63-68.

Pedersen NC, Ekman S and Laliberte L (1983). A transient febrile "limping" syndrome of kittens caused by two different strains of feline calicivirus. Feline Pract. 13: 26-35.

SiTu ZQ (2004). Cell culture. World Publishing Company, New York, 315-325. 
Wang XS, Xia XZ and Fan Q (1999). Tiger outbreaks of trypanosomiasis. Zhong Guo Shou Yi Ke Ji 29: 34-35.

Wang Y, Ren LS, Li YD and et al. (2008). Anti-chloramphenicol monoclonal antibody preparation, purification and its specific identification. Ji Lin Da Xue Xue Bao: Yi Xue Ban 34: 336-339.

Waters L, Hopper CD, Gruffydd-Jones TJ and Harbour DA (1993). Chronic gingivitis in a colony of cats infected with feline immunodeficiency virus and feline calicivirus. Vet. Rec. 132: 340-342.

Yin Z and Liu JH (1997). Animal Virology. 2nd edn. Science Press, Beijing, 519-531. 